\title{
IMPLEMENTASI KONSEP JAMINAN SYARIAH DALAM TATA ATURAN UU PERBANKAN SYARIAH
}

\author{
Noor Hafidah \\ Dosen Fakultas Hukum Universitas Lambung Mangkurat \\ Email: hafidahnoor@gmail.com
}

\begin{abstract}
Islamic Banking known as bank financial institutions based on Sharia Principles. In terms of recognizing the Islamic banking operations, including distribution and collection of public funds should be based on the principle syaiah as the implementation of sharia compliance.

As like conventional banking, the implementation of security systems implemented to protect public funds. Collateral system applied in Islamic banking is not base on syaria collateral but.

Within the framework of Shariah compliance or compliance syaria, syaria banking should implement syaria collateral. Based on research Islamic Banking Act No. 21/2008 as the implementation of Islamic banking regulations do not expressly regulate about sharia collateral, as well as other implementing regulations such as Bank Indonesia Circular Letter. Therefore, in compliance to obey sharia compliance or syaria compliance should be made to implementing regulations that provide clarity on the status of sharia collateral, which is part of comprehensif the Islamic banking
\end{abstract}

Keyword: Islamic Banking, Sharia Collateral .

\begin{abstract}
Abstrak
Perbankan Syariah kita kenal sebagai lembaga keuangan bank berdasarkan pada Prinsip-Prinsip Syariah. Dalam hal yang demikian maka operasionalisasi perbankan syariah yang meliputi penyaluran dan penghimpunan dana masyarakat harus berdasarkan prinsip syaiah sebagai implementasi atas kepatuhan syariah atau syaria compliance.

Khusus penyaluran dana sebagaimana perbankan konvensional, perbankan syariah juga menerapkan sistem jaminan sebagai implementasi dalam melindungi dana masyarakat. Sistem jaminan yang diterapkan dalam perbankan syariah adalah sistem jaminan konvensional bukan sistem jaminan syariah atau sistem jaminan yang berdasarkan pada prinsip syariah. Dalam kerangka kepatuhan syariah atau syaria compliance sudah seharusnya perbankan syariah menerapkan jaminan syariah. Berdasarkan hasil penelitian penulis UU No. 21 Tahun 2008 tentang Undang-Undang Perbankan Syariah sebagai regulasi pelaksanaan perbankan syariah tidak secara tegas mengatur tentang jaminan syariah, demikian pula peraturan pelaksana lainnya seperti Surat Edaran Bank Indonesia. Oleh karena itu dalam kerangka pemenuhan kepatuhan syariah atau syaria compliance sebaiknya dibuat peraturan pelaksana yang memberikan kejelasan atas kedudukan jaminan syariah yang merupakan bagian yang komphensif dalam sistem perbankan syariah.
\end{abstract}

Kata Kunci: Perbankan Syariah, Jaminan Syariah.

\section{Latar Belakang}

Dalam memberikan pembiayaan atau menyalurkan dana kepada nasabah, Bank Syariah dan/ atau Unit Usaha Syariah terlebih dahulu harus mempunyai keyakinan bahwa nasabah mempu- nyai kemauan dan kemampuan untuk melunasi fasilitas pendanaan yang mereka terima. Untuk sampai kepada keyakinan tersebut, Bank Syariah dan/atau Unit Usaha Syariah wajib melakukan penilaian secara seksama terhadap watak, kemam- 
puan, modal, agunan dan prospek usaha dari calon nasabah penerima fasilitas pendanaan. Sehubungan dengan implementasi Pasal 23 UU Perbankan Syariah, Bank Indonesia telah menerbitkan berbagai Peraturan Bank Indonesia (PBI) dan Surat Edaran Bank Indonesia (SEBI), yang hanya berkaitan dengan pembiayaan syariah.

Mengingat jaminan syariah tidak diatur dalam UU Perbankan, UU Perbankan Syariah, Peraturan Bank Indonesia (PBI), dan Surat Edaran Bank Indonesia (SBI), secara faktual Bank umum (melalui UUS) yang memberikan pembiayaan berdasarkan syariah dan Bank Syariah yang memberikan pembiayaan syariah tetap memberlakukan jaminan konvensional. Secara yuridis formal, kegiatan pembiayaan berdasarkan syariah tidak bertentangan dengan undang-undang, tetapi apabila dianalisis lebih lanjut menimbulkan persoalan dalam konteks syariah itu sendiri. Dalam konteks syariah, pembiayaan syariah (yang merupakan akad dan menjadi bagian dari perikatan syariah) harus dikaitkan dengan jaminan syariah. Dengan demikian, pembiayaan berdasarkan syariah dalam perbankan syariah tetapi tidak memberlakukan jaminan syariah merupakan tindakan yang bertentangan dengan prinsip syariah. Persoalan ini perlu segera mendapatkan penyelesaian.

Sebenarnya kekhususan karakteristik pembiayaan syariah dalam perbankan syariah sudah diingatkan dalam konsiderans butir (c) Undang-Undang Perbankan Syariah, secara tegas menentukan bahwa perbankan syariah memiliki kekhususan dibandingkan dengan perbankan konvensional. Jadi, perbankan syariah merupakan perbankan yang seharusnya diperlakukan secara berbeda dan secara khusus.

Selain itu juga diingatkan dalam Penjelasan Umum UU Perbankan Syariah, yaitu sebagai berikut:

1. Agar tercapai tujuan pembangunan nasional dan dapat berperan aktif dalam persaingan global yang sehat, diperlukan partisipasi dan kontribusi semua elemen masyarakat untuk menggali berbagai potensi yang ada di masyarakat guna mendukung proses akselerasi ekonomi dalam upaya merealisasikan tujuan pembangunan nasional. Salah satu bentuk penggalian potensi dan wujud kontribusi masyarakat dalam perekonomian nasional tersebut adalah pengembangan sistem ekonomi berdasarkan nilai Islam (Syariah) dengan mengangkat prinsip-prinsipnya ke dalam Sistem Hukum Nasional. Prinsip Syariah berlandaskan pada nilai-nilai keadilan, kemanfaatan, keseimbangan, dan keuniversalan (rahmatan lil 'alamin). Nilainilai tersebut diterapkan dalam pengaturan perbankan yang didasarkan pada Prinsip Syariah yang disebut Perbankan Syariah.

2. Perbankan Syariah sebagai salah satu sistem perbankan nasional memerlukan berbagai sarana pendukung agar dapat memberikan kontribusi yang maksimum bagi pengembangan ekonomi nasional. Salah satu sarana pendukung vital adalah adanya pengaturan yang memadai dan sesuai dengan karakteristiknya. Pengaturan tersebut di antaranya dituangkan dalam Undang-Undang Perbankan Syariah. Pembentukan Undang-Undang Perbankan Syariah menjadi kebutuhan dan keniscayaan bagi berkembangnya lembaga tersebut. Pengaturan mengenai Perbankan Syariah dalam Undang-Undang Nomor 7 Tahun 1992 tentang Perbankan sebagaimana telah diubah dengan Undang-Undang Nomor 10 Tahun 1998 belum spesifik dan kurang mengakomodasi karakteristik operasional Perbankan Syariah, dimana di sisi lain pertumbuhan dan volume usaha Bank Syariah berkembang cukup pesat.

3. Sebagaiundang-undangyang khusus mengatur perbankan syariah, dalam Undang-Undang ini diatur mengenai masalah kepatuhan syariah (syariah compliance) yang kewenangannya berada pada Majelis Ulama Indonesia (MUI) yang direpresentasikan melalui Dewan Pengawas Syariah (DPS) yang harus dibentuk pada masing-masing Bank Syariah dan UUS. Untuk menindaklanjuti implementasi fatwa yang dikeluarkan MUI ke dalam Peraturan Bank Indonesia, di dalam internal Bank Indonesia dibentuk komite perbankan syariah, yang keanggotaannya terdiri atas perwakilan dari Bank Indonesia, Departemen Agama, dan unsur masyarakat yang komposisinya berimbang. Sementara itu, penyelesaian sengketa yang mungkin timbul pada perbankan syariah, akan dilakukan melalui pengadilan di lingkungan Peradilan Agama. 
Berdasarkan konsideran huruf (c) dan beberapa butir dalam Penjelasan Umum UU Perbankan Syariah, tidak ada keraguan tentang kekhususan perbankan syariah dengan salah satu produk utamanya adalah pembiayaan syariah, dan kekhususan ini harus dimuat dalam UU Perbankan Syariah. Menjadi persoalan adalah jaminan syariah yang merupakan bagian integral dari pembiayaan syariah dalam perbankan syariah sama sekali tidak diatur.

Oleh karena itu patut dianalisis sebuah issue hukum berkaitan tentang jaminan syariah tersebut, yaitu bagaimana implementasi konsep jaminan syariah pada operasionalisasi perbankan syariah.

\section{Pembahasan}

\section{a. Konsep Jaminan Syariah}

Sebelum menganalisasi implementasi konsep jaminan syariah, perlu pemahaman mengenai jaminan syariah. Pemahaman ini dimulai dari pengertian tentang jaminan.

Jaminan dalam bahasa Arab dikenal dengan istilah al-rahn. Al-rahn dalam bahasa Arab memiliki pengertian tetap dan terus-menerus, yang dida-

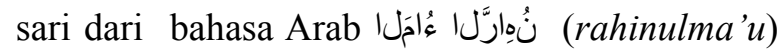
yang artinya apabila tidak mengalir dan kata

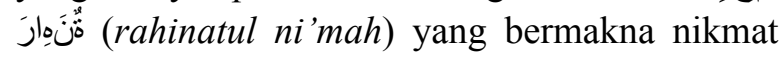
yang tidak putus. ${ }^{1}$ Dalam Islamic Jurisprudential, al-rahn (mortgage or security money) means possesions offered as security for a debt so that the debt will be taken from them in case the debtor failed to pay back the due money. ${ }^{2}$

Menurut Sayyid As-Sabiq, al-rahn menurut syara' memiliki arti menjadikan suatu barang yang mempunyai nilai harta dalam pandangan syara' sebagai jaminan hutang, yang memungkinkan untuk mengambil seluruh/sebagian hutang dari barang tersebut. ${ }^{3}$

Dengan demikian, esensi al-rahn adalah menahan barang milik debitur atau si peminjam (rahin) yang mempunyai nilai ekonomis sebagai jaminan untuk menjamin pelunasan hutang debitur kepada kreditur atau yang memberikan pinjaman (marhunbih). Dalam al-rahn terdapat unsur adanya barang yang dijadikan jaminan, barang yang dijadikan jaminan tersebut bernilai ekonomis dan bermanfaat serta dapat dimanfaatkan oleh marhunbih sebagai penerima al-rahn. Memberikan manfaat disini dimaksudkan bahwa al-rahn memberikan ketenangan kepada marhunbih (pemilik uang) dan atau jaminan keamanan uang yang dipinjamkan. Selain itu, unsur yang penting lainnya timbulnya al-rahn dikarenakan adanya perjanjian utang piutang yang mendahuluinya. Dalam konsep hukum perjanjian dalam BW, al-rahn dapat dianalogkan sebagai perjanjian 'accesoir' atau perjanjian ikutan (tambahan).

Sebagai konsep hukum jaminan, al-rahn dapat dianalogkan sebagai lembaga jaminan, sebagaimana lembaga jaminan konvensional lain yang juga merupakan perjanjian 'accesoir', yaitu hak tanggungan, fidusia dan gadai.

\section{b. Implementasi Pada Tataran Aturan Hukum}

Sejak tanggal 16 Juli 2008, segala sesuatu yang berkaitan dengan perbankan syariah, terutama yang bersangkut paut dengan persoalan kelembagaan, kegiatan usaha, serta cara dan proses dalam melaksanakan kegiatan usahanya, diatur oleh UU Nomor 21 Tahun 2008 tentang Perbankan Syariah (Undang-Undang Perbankan Syariah).

Urgensi dan signifikansi diundangkannya Undang-Undang Perbankan Syariah dapat disimpulkan dari konsiderans Undang-Undang Perbankan Syariah yang menyatakan bahwa:

1. Sejalan dengan tujuan pembangunan nasional Indonesia untuk mencapai terciptanya masyarakat adil dan makmur berdasarkan demokrasi ekonomi, dikembangkan sistem ekonomi yang berlandaskan pada nilai keadilan, kebersamaan, pemerataan, dan kemanfaatan yang sesuai dengan prinsip syariah;

2. Kebutuhan masyarakat Indonesia akan jasajasa perbankan syariah semakin meningkat;

3. Perbankan syariah memiliki kekhususan dibandingkan dengan perbankan konvensional; 
4. Pengaturan mengenai perbankan syariah di dalam Undang-Undang Nomor 7 Tahun 1992 tentang Perbankan sebagaimana telah diubah dengan Undang-Undang Nomor 10 Tahun 1998 belum spesifik sehingga perlu diatur secara khusus dalam suatu undang-undang tersendiri; dan (e) berdasarkan pertimbangan sebagaimana dimaksud dalam huruf a, huruf $\mathrm{b}$, huruf $\mathrm{c}$, dan huruf $\mathrm{d}$ perlu membentuk Undang-Undang tentang Perbankan Syariah.

Kemauan untuk membentuk perbankan syariah juga didasarkan pada berbagai pertimbangan, sebagaimana terdapat Penjelasan Umum Undang-Undang Perbankan Syariah, yaitu:

1. Agar tercapai tujuan pembangunan nasional dan dapat berperan aktif dalam persaingan global yang sehat, diperlukan partisipasi dan kontribusi semua elemen masyarakat untuk menggali berbagai potensi yang ada di masyarakat guna mendukung proses akselerasi ekonomi dalam upaya merealisasikan tujuan pembangunan nasional. Salah satu bentuk penggalian potensi dan wujud kontribusi masyarakat dalam perekonomian nasional tersebut adalah pengembangan sistem ekonomi berdasarkan nilai Islam (Syariah) dengan mengangkat prinsip-prinsipnya ke dalam Sistem Hukum Nasional. Prinsip Syariah berlandaskan pada nilai-nilai keadilan, kemanfaatan, keseimbangan, dan keuniversalan (rahmatan lil 'alamin). Nilainilai tersebut diterapkan dalam pengaturan perbankan yang didasarkan pada Prinsip Syariah yang disebut Perbankan Syariah;

2. Prinsip Perbankan Syariah merupakan bagian dari ajaran Islam yang berkaitan dengan ekonomi. Salah satu prinsip dalam ekonomi Islam adalah larangan riba dalam berbagai bentuknya, dan menggunakan sistem antara lain prinsip bagi hasil. Dengan prinsip bagi hasil, Bank Syariah dapat menciptakan iklim investasi yang sehat dan adil karena semua pihak dapat saling berbagi baik keuntungan maupun potensi risiko yang timbul sehingga akan menciptakan posisi yang berimbang antara bank dan nasabahnya. Dalam jangka panjang, hal ini akan mendorong pemerataan ekonomi nasional karena hasil keuntungan tidak hanya dinikmati oleh pemilik modal saja, tetapi juga oleh pengelola modal;
3. Perbankan Syariah sebagai salah satu sistem perbankan nasional memerlukan berbagai sarana pendukung agar dapat memberikan kontribusi yang maksimum bagi pengembangan ekonomi nasional. Salah satu sarana pendukung vital adalah adanya pengaturan yang memadai dan sesuai dengan karakteristiknya. Pengaturan tersebut di antaranya dituangkan dalam Undang-Undang Perbankan Syariah. Pembentukan Undang-Undang Perbankan Syariah menjadi kebutuhan dan keniscayaan bagi berkembangnya lembaga tersebut. Pengaturan mengenai Perbankan Syariah dalam Undang-Undang Nomor 7 Tahun 1992 tentang Perbankan sebagaimana telah diubah dengan Undang-Undang Nomor 10 Tahun 1998 belum spesifik dan kurang mengakomodasi karakteristik operasional Perbankan Syariah, dimana, di sisi lain pertumbuhan dan volume usaha Bank Syariah berkembang cukup pesat.

Semua uraian di atas, pada hakekatnya merupakan political will (kemauan politik) dan political back up (dukungan politik) pemerintah untuk menerapkan prinsip-prinsip syariah dalam dunia perbankan, dengan membidani kelahiran perbankan syariah di Indonesia yang secara kelembagaan dilaksanakan oleh Bank Syariah dan Unit Usaha Syariah (UUS).

Political will dan political back up ini memang sudah sepatutnya dilakukan oleh pemerintah mengingat urgensi dan signifikansi keberadaan serta peran perbankan syariah. Perbankan syariah yang dikelola secara profesional dengan dukungan berbagai sarana vital akan mampu menjadi salah satu subsistem perbankan nasional yang memberikan kontribusi maksimal bagi pengembangan ekonomi nasional. Hal lain yang menjadi alasan adalah pertumbuhan dan volume usaha Bank Syariah ternyata berkembang cukup pesat.

Jika dianalisis, pertimbangan dibuatnya Undang-Undang Perbankan Syariah dapat dikatakan sesuai dengan kondisi penduduk Indonesia secara demografis, dimana selain mayoritas penduduk beragama Islam, juga mayoritas penduduk yang beragama Islam merupakan golongan penduduk ekonomi lemah. Kehadiran perbankan yang dikelola dengan prinsip-prinsip syariah akan dipandang sesuai dengan rasa 
keagamaan mereka, selain diharapkan mampu meningkatkan kesejahteraan mereka.

Persoalan hukum yang perlu dikemukakan di sini adalah apakah aturan hukum yang diwujudkan dalam pasal-pasal Undang-Undang Perbankan Syariah telah mengimplementasikan esensi konsep jaminan syariah (al-rahn). Beberapa aspek dalam Undang-Undang Perbankan Syariah yang perlu dianalisis dalam kaitannya dengan implementasi esensi konsep jaminan syariah (al-rahn) adalah Asas Hukum, kegiatan usaha, juga cara dan proses dalam melaksanakan kegiatan usahanya.

Asas yang mendasari kegiatan usaha perbankan syariah diatur dalam Pasal 2 UndangUndang Perbankan Syariah yang menentukan, bahwa "Perbankan Syariah dalam melakukan kegiatan usahanya berasaskan Prinsip Syariah, demokrasi ekonomi, dan prinsip kehati-hatian".

Pengertian masing-masing asas dijelaskan dalam penjelasan Pasal 2 Undang-Undang Perbankan Syariah. Kegiatan usaha yang berasaskan Prinsip Syariah, antara lain, adalah kegiatan usaha yang tidak mengandung unsur: (a) riba, yaitu penambahan pendapatan secara tidak sah (batil) antara lain dalam transaksi pertukaran barang sejenis yang tidak sama kualitas, kuantitas, dan waktu penyerahan $(f a d h l)$, atau dalam transaksi pinjam-meminjam yang mempersyaratkan Nasabah Penerima Fasilitas mengembalikan dana yang diterima melebihi pokok pinjaman karena berjalannya waktu (nasi'ah); (b) maisir, yaitu transaksi yang digantungkan kepada suatu keadaan yang tidak pasti dan bersifat untung-untungan; (c) gharar, yaitu transaksi yang objeknya tidak jelas, tidak dimiliki, tidak diketahui keberadaannya, atau tidak dapat diserahkan pada saat transaksi dilakukan kecuali diatur lain dalam syariah; (d) haram, yaitu transaksi yang objeknya dilarang dalam syariah; atau (e) zalim, yaitu transaksi yang menimbulkan ketidakadilan bagi pihak lainnya.

Dalam rejim UU Perbankan Syariah, prinsip syariah sebagai prinsip hukum Islam dalam kegiatan perbankan didasarkan pada fatwa yang dikeluarkan oleh lembaga yang memiliki kewenangan dalam penetapan fatwa di bidang syariah (Pasal 1 angka 12 Undang-Undang Perbankan Syariah). Demokrasi ekonomi adalah kegiatan ekonomi syariah yang mengandung nilai keadilan, kebersamaan, pemerataan, dan kemanfaatan, sedang yang dimaksud dengan prinsip kehati-hatian adalah pedoman pengelolaan Bank yang wajib dianut guna mewujudkan perbankan yang sehat, kuat, dan efisien sesuai dengan ketentuan peraturan perundang-undangan.

Aturan hukum yang terdapat dalam Pasal 2 Undang-Undang Perbankan Syariah yang mengatur tentang Asas Perbankan Syariah merupakan pen'degradasi' an (penurunan tataran) terhadap asas-asas dalam Syariah.

Bidang muamalah yang di dalamnya meliputi perikatan syariah dan jaminan syariah (keduanya merupakan perbuatan hukum yang utama dalam perbankan syariah) dilaksanakan dengan didasarkan atas beberapa asas, yaitu $\mathrm{Al}$ Hurriyah (Asas Kebebasan), Al-Musawah (Persamaan dan Kesetaraan), Al-'Adalah (keadilan), Al-Ridha (Kerelaan), Ash-Shidq (Kejujuran dan Kebenaran); dan Al-Kitabah (Tertulis) ${ }^{4}$. Selain itu terdapat pula asas tolong menolong dalam rangka mencari ridho Allah SWT dan asas kehati-hatian dengan adanya barang tanggungan dalam akad utang-piutang. Dengan adanya beberapa asas yang melandasi muamalah, sebenarnya asas-asas yang terdapat dalam Pasal 2 Undang-Undang Perbankan Syariah merupakan sebagian saja dari asas-asas dalam syariah. Dengan demikian, rumusan Pasal 2 Undang-Undang Perbankan Syariah selain berlebihan, juga men'degradasi'kan asas-asas dalam syariah. Kiranya patut untuk dikatakan bahwa rumusan Pasal 2 UndangUndang Perbankan Syariah seyogyanya adalah sebagai berikut: "Perbankan Syariah dalam melakukan kegiatan usahanya berasaskan pada prinsip-prinip Syariah"

Tujuan dibentuk dan dilaksanakannya Perbankan Syariah sesuai dengan salah satu tujuan muamalah yaitu 'rahmatan lil alamin'. Hal ini telah terimplementasi dalam rumusan pasal 3 UndangUndang Perbankan Syariah yang menentukan, bahwa "Perbankan Syariah bertujuan menunjang pelaksanaan pembangunan nasional dalam rangka meningkatkan keadilan, kebersamaan, dan pemerataan kesejahteraan rakyat". Paling tidak, tujuan dibentuknya perbankan syariah telah mencerminkan karakteristik muamalah sebagai wahana untuk menciptakan rahmat bagi semesata alam

4. Gemala Dewi, Hukum Perikatan Islam di Indonesia, Kencana, Jakarta, 2006, hlm. 30 
terutama bagi umat manusia. Untuk mencapai tujuan menunjang pelaksanaan pembangunan nasional, Perbankan Syariah tetap berpegang pada Prinsip Syariah secara menyeluruh (kaffah) dan konsisten (istiqamah), demikian ditegaskan dalam penjelasan Pasal 3 Undang-Undang Perbankan Syariah

Yang diperkenankan melakukan kegiatan perbankan syariah adalah Bank Syariah dan Unit Usaha Syariah, demikian esensi Pasal 1 angka (1) Undang-Undang Perbankan Syariah. Menurut Pasal 18 Undang-Undang Perbankan Syariah, Bank Syariah terdiri atas Bank Umum Syariah dan Bank Pembiayaan Rakyat Syariah. Demikian juga ketentuan Pasal 1 angka (7) Undang-Undang Perbankan Syariah yang menentukan bahwa Bank Syariah adalah Bank yang menjalankan kegiatan usahanya berdasarkan Prinsip Syariah dan menurut jenisnya terdiri atas Bank Umum Syariah dan Bank Pembiayaan Rakyat Syariah.

Perbedaan antara Bank Umum Syariah dan Bank Pembiayaan Rakyat Syariah adalah Bank Umum Syariah dalam kegiatannya memberikan jasa dalam lalu lintas pembayaran, sedang Bank Pembiayaan Rakyat Syariah dalam kegiatannya tidak memberikan jasa dalam lalu lintas pembayaran, demikian ketentuan Pasal 1 angka (8) dan (9).

Unit Usaha Syariah (UUS) adalah unit kerja dari kantor pusat Bank Umum Konvensional yang berfungsi sebagai kantor induk dari kantor atau unit yang melaksanakan kegiatan usaha berdasarkan Prinsip Syariah, atau unit kerja di kantor cabang dari suatu Bank yang berkedudukan di luar negeri yang melaksanakan kegiatan usaha secara konvensional yang berfungsi sebagai kantor induk dari kantor cabang pembantu syariah dan/atau unit syariah, demikian ketentuan Pasal 1 angka (10) Undang-Undang Perbankan Syariah.

Kegiatan utama perbankan syariah sebagaimana diatur dalam Undang-Undang Perbankan Syariah adalah menghimpun dana dari masyarakat dan menyalurkan biaya (dana), dan kegiatan yang secara langsung yang berhubungan dengan keberadaaan dan peran jaminan syariah (al-rahn) adalah kegiatan yang berupa pembiayaan (penyaluran dana). Berkaitan dengan pembiayaan, Pasal 1 angka (25) menentukan Pembiayaan adalah penyediaan dana atau tagihan yang dipersamakan dengan itu berupa:
1. transaksi bagi hasil dalam bentuk mudharabah dan musyarakah;

2. transaksi sewa-menyewa dalam bentuk ijarah atau sewa beli dalam bentuk ijarah muntahiya bittamlik;

3. transaksi jual beli dalam bentuk piutang murabahah, salam, dan istishna;

4. transaksi pinjam meminjam dalam bentuk piutang qardh; dan

5. transaksi sewa-menyewa jasa dalam bentuk ijarah untuk transaksi multijasa berdasarkan persetujuan atau kesepakatan antara Bank Syariah dan/atau UUS dan pihak lain yang mewajibkan pihak yang dibiayai dan/atau diberi fasilitas dana untuk mengembalikan dana tersebut setelah jangka waktu tertentu dengan imbalan ujrah, tanpa imbalan, atau bagi hasil'"

Kegiatan usaha Bank Umum Syariah diatur dalam Pasal 19 ayat (1) Undang-Undang Perbankan Syariah yang menentukan:

"Kegiatan usaha Bank Umum Syariah meliputi:

1. menghimpun dana dalam bentuk Simpanan berupa Giro, Tabungan, atau bentuk lainnya yang dipersamakan dengan itu berdasarkan Akad wadi'ahatau Akad lain yang tidak bertentangan dengan Prinsip Syariah;

2. menghimpun dana dalam bentuk Investasi berupa Deposito, Tabungan, atau bentuk lainnya yang dipersamakan dengan itu berdasarkan Akad mudharabah atau Akad lain yang tidak bertentangan dengan Prinsip Syariah;

3. menyalurkan Pembiayaan bagi hasil berdasarkan Akad mudharabah, Akad musyarakah, atau Akad lain yang tidak bertentangan dengan Prinsip Syariah;

4. menyalurkan Pembiayaan berdasarkan Akad murabahah, Akad salam, Akad istishna', atau Akad lain yang tidak bertentangan dengan Prinsip Syariah;

5. menyalurkan Pembiayaan berdasarkan Akad qardh atau Akad lain yang tidak bertentangan dengan Prinsip Syariah;

6. menyalurkan Pembiayaan penyewaan barang bergerak atau tidak bergerak kepada Nasabah berdasarkan Akad ijarah dan/atau sewa beli dalam bentuk ijarah muntahiya bittamlik atau Akad lain yang tidak bertentangan dengan 
Prinsip Syariah;

7. melakukan pengambilalihan utang berdasarkan Akad hawalah atau Akad lain yang tidak bertentangan dengan Prinsip Syariah;

8. melakukan usaha kartu debit dan/atau kartu pembiayaan berdasarkan Prinsip Syariah;

9. membeli, menjual, atau menjamin atas risiko sendiri surat berharga pihak ketiga yang diterbitkan atas dasar transaksi nyata berdasarkan Prinsip Syariah, antara lain, seperti Akad ijarah, musyarakah, mudharabah, murabahah, kafalah, atau hawalah;

10. membeli surat berharga berdasarkan Prinsip Syariah yang diterbitkan oleh pemerintah dan/ atau Bank Indonesia;

11. menerima pembayaran dari tagihan atas surat berharga dan melakukan perhitungan dengan pihak ketiga atau antarpihak ketiga berdasarkan Prinsip Syariah;

12. melakukan Penitipan untuk kepentingan pihak lain berdasarkan suatu Akad yang berdasarkan Prinsip Syariah;

13. menyediakan tempat untuk menyimpan barang dan surat berharga berdasarkan Prinsip Syariah;

14. memindahkan uang, baik untuk kepentingan sendiri maupun untuk kepentingan Nasabah berdasarkan Prinsip Syariah;

15. melakukan fungsi sebagai Wali Amanat berdasarkan Akad wakalah;

16. memberikan fasilitas letter of credit atau bank garansi berdasarkan Prinsip Syariah; dan

17. melakukan kegiatan lain yang lazim dilakukan di bidang perbankan dan di bidang sosial sepanjang tidak bertentangan dengan Prinsip Syariah dan sesuai dengan ketentuan peraturan perundang-undangan.

Selain kegiatan usaha di atas, Bank Umum Syariah juga dapat melakukan kegiatan usaha sbagaimana diatur dalam Pasal 20 ayat (1) Undang-Undang Perbankan Syariah, yaitu:

1. melakukan kegiatan valuta asing berdasarkan Prinsip Syariah;

2. melakukan kegiatan penyertaan modal pada Bank Umum Syariah atau lembaga keuangan yang melakukan kegiatan usaha berdasarkan Prinsip Syariah;

3. melakukan kegiatan penyertaan modal sementara untuk mengatasi akibat kegagalan Pembi- ayaan berdasarkan Prinsip Syariah, dengan syarat harus menarik kembali penyertaannya;

4. bertindak sebagai pendiri dan pengurus dana pensiun berdasarkan Prinsip Syariah;

5. melakukan kegiatan dalam pasar modal sepanjang tidak bertentangan dengan Prinsip Syariah dan ketentuan peraturan perundangundangan di bidang pasar modal;

6. menyelenggarakan kegiatan atau produk bank yang berdasarkan Prinsip Syariah dengan menggunakan sarana elektronik;

7. menerbitkan, menawarkan, dan memperdagangkan surat berharga jangka pendek berdasarkan Prinsip Syariah, baik secara langsung maupun tidak langsung melalui pasar uang;

8. menerbitkan, menawarkan, dan memperdagangkan surat berharga jangka panjang berdasarkan Prinsip Syariah, baik secara langsung maupun tidak langsung

9. melalui pasar modal; dan

10. menyediakan produk atau melakukan kegiatan usaha Bank Umum Syariah lainnya yang berdasarkan Prinsip Syariah.

Sebagaimana telah dijelaskan yang berkaitan dengan al-rahn adalah kegiatan usaha perbankan syariah yang berupa pembiayaan (penyaluran dana). Pengertian dari beberapa konsep dalam hal pembiayaan diatur dalam penjelasan Pasal 19 ayat (1) Undang-Undang Perbankan Syariah, sebagai berikut:

1. Akad mudharabah dalam Pembiayaan adalah Akad kerja sama suatu usaha antara pihak pertama (malik, shahibul mal, atau Bank Syariah) yang menyediakan seluruh modal dan pihak kedua ('amil, mudharib, atau Nasabah) yang bertindak selaku pengelola dana dengan membagi keuntungan usaha sesuai dengan kesepakatan yang dituangkan dalam Akad, sedangkan kerugian ditanggung sepenuhnya oleh Bank Syariah kecuali jika pihak kedua melakukan kesalahan yang disengaja, lalai atau menyalahi perjanjian;

2. Akad musyarakah adalah Akad kerja sama di antara dua pihak atau lebih untuk suatu usaha tertentu yang masing-masing pihak memberikan porsi dana dengan ketentuan bahwa keuntungan akan dibagi sesuai dengan kesepakatan, sedangkan kerugian ditanggung sesuai dengan porsi dana masing-masing; 
3. Akad murabahah adalah Akad Pembiayaan suatu barang dengan menegaskan harga belinya kepada pembeli dan pembeli membayarnya dengan harga yang lebih sebagai keuntungan yang disepakati;

4. Akad salam adalah Akad Pembiayaan suatu barang dengan cara pemesanan dan pembayaran harga yang dilakukan terlebih dahulu dengan syarat tertentu yang disepakati;

5. Akad istishna adalah Akad Pembiayaan barang dalam bentuk pemesanan pembuatan barang tertentu dengan kriteria dan persyaratan tertentu yang disepakati antara pemesan atau pembeli (mustashni') dan penjual atau pembuat (shani');

6. Akad qardh adalah Akad pinjaman dana kepada Nasabah dengan ketentuan bahwa Nasabah wajib mengembalikan dana yang diterimanya pada waktu yang telah disepakati;

7. Akad ijarah adalah Akad penyediaan dana dalam rangka memindahkan hak guna atau manfaat dari suatu barang atau jasa berdasarkan transaksi sewa, tanpa diikuti dengan pemindahan kepemilikan barang itu sendiri;

8. Akad ijarah muntahiya bittamlik adalah Akad penyediaan dana dalam rangka memindahkan hak guna atau manfaat dari suatu barang atau jasa berdasarkan transaksi sewa dengan opsi pemindahan kepemilikan barang;

9. Akad hawalah adalah Akad pengalihan utang dari pihak yang berutang kepada pihak lain yang wajib menanggung atau membayar;

10. Transaksi nyata adalah transaksi yang dilandasi dengan aset yang berwujud.; dan

11. Akad kafalah adalah Akad pemberian jaminan yang diberikan satu pihak kepada pihak lain, di mana pemberi jaminan (kafil) bertanggung jawab atas pembayaran kembali utang yang menjadi hak penerima jaminan ( $m a k f u l$ ).

Pasal 19 ayat (2) Undang-Undang Perbankan

Syariah mengatur kegiatan Unit Usaha Syariah (UUS), sebagai berikut:

1. menghimpun dana dalam bentuk Simpanan berupa Giro, Tabungan, atau bentuk lainnya yang dipersamakan dengan itu berdasarkan Akad wadi'ah atau Akad lain yang tidak bertentangan dengan Prinsip Syariah;

2. menghimpun dana dalam bentuk Investasi berupa Deposito, Tabungan, atau bentuk lainnya yang dipersamakan dengan itu berdasarkan Akad mudharabah atau Akad lain yang tidak bertentangan dengan Prinsip Syariah;

3. menyalurkan Pembiayaan bagi hasil berdasarkan Akad mudharabah, Akad musyarakah, atau Akad lain yang tidak bertentangan dengan Prinsip Syariah;

4. menyalurkan Pembiayaan berdasarkan Akad murabahah, Akad salam, Akad istishna', atau Akad lain yang tidak bertentangan dengan Prinsip Syariah;

5. menyalurkan Pembiayaan berdasarkan Akad qardh atau Akad lain yang tidak bertentangan dengan Prinsip Syariah;

6. menyalurkan Pembiayaan penyewaan barang bergerak atau tidak bergerak kepada Nasabah berdasarkan Akad ijarah dan/atau sewa beli dalam bentuk ijarah muntahiya bittamlik atau Akad lain yang tidak bertentangan dengan Prinsip Syariah;

7. melakukan pengambilalihan utang berdasarkan Akad hawalah atau Akad lain yang tidak bertentangan dengan Prinsip Syariah;

8. melakukan usaha kartu debit dan/atau kartu pembiayaan berdasarkan Prinsip Syariah;

9. membeli dan menjual surat berharga pihak ketiga yang diterbitkan atas dasar transaksi nyata berdasarkan Prinsip Syariah, antara lain, seperti Akad ijarah, musyarakah, mudharabah, murabahah, kafalah, atau hawalah;

10. membeli surat berharga berdasarkan Prinsip Syariah yang diterbitkan oleh pemerintah dan/ atau Bank Indonesia;

11. menerima pembayaran dari tagihan atas surat berharga dan melakukan perhitungan dengan pihak ketiga atau antarpihak ketiga berdasarkan Prinsip Syariah;

12. menyediakan tempat untuk menyimpan barang dan surat berharga berdasarkan Prinsip Syariah;

13. memindahkan uang, baik untuk kepentingan sendiri maupun untuk kepentingan Nasabah berdasarkan Prinsip Syariah;

14. memberikan fasilitas letter of credit atau bank garansi berdasarkan Prinsip Syariah; dan

15. melakukan kegiatan lain yang lazim dilakukan di bidang perbankan dan di bidang sosial sepanjang tidak bertentangan dengan Prinsip 
Syariah dan sesuai dengan ketentuan peraturan perundang-undangan"

Unit Usaha Syariah (UUS) juga dapat melakukan kegiatan usaha lainnya sebagaimana diatur dalam Pasal 20 ayat (2) Undang-Undang Perbankan Syariah, yaitu:

1. melakukan kegiatan valuta asing berdasarkan Prinsip Syariah;

2. melakukan kegiatan dalam pasar modal sepanjang tidak bertentangan dengan Prinsip Syariah dan ketentuan peraturan perundangundangan di bidang pasar modal;

3. melakukan kegiatan penyertaan modal sementara untuk mengatasi akibat kegagalan Pembiayaan berdasarkan Prinsip Syariah, dengan syarat harus menarik kembali penyertaannya;

4. menyelenggarakan kegiatan atau produk bank yang berdasarkan Prinsip Syariah dengan menggunakan sarana elektronik;

5. menerbitkan, menawarkan, dan memperdagangkan surat berharga jangka pendek berdasarkan Prinsip Syariah baik secara langsung maupun tidak langsung melalui pasar uang; dan

6. menyediakan produk atau melakukan kegiatan usaha Bank Umum Syariah lainnya yang berdasarkan Prinsip Syariah.

Tetapi kegiatan usaha Bank Umum Syariah dan Unit Usaha Syariah (UUS) sebagaimana diatur dalam Pasal 20 ayat (1) dan (2) wajib memenuhi ketentuan yang ditetapkan oleh Bank Indonesia dan ketentuan peraturan perundang-undangan, demikian ketentuan Pasal 20 ayat (3) UndangUndang Perbankan Syariah.

Kegiatan usaha Bank Pembiayaan Rakyat Syariah diatur dalam Pasal 21 Undang-Undang Perbankan Syariah, yang menentukan:

Kegiatan usaha Bank Pembiayaan Rakyat Syariah meliputi:

1. menghimpun dana dari masyarakat dalam bentuk:

a. Simpanan berupa Tabungan atau yang dipersamakan dengan itu berdasarkan Akad wadi'ah atau Akad lain yang tidak bertentangan dengan Prinsip Syariah; dan

b. Investasi berupa Deposito atau Tabungan atau bentuk lainnya yang dipersamakan dengan itu berdasarkan Akad mudharabah atau Akad lain yang tidak bertentangan dengan Prinsip Syariah;

2. menyalurkan dana kepada masyarakat dalam bentuk:

a. Pembiayaan bagi hasil berdasarkan Akad mudharabah atau musyarakah;

b. Pembiayaan berdasarkan Akad murabahah, salam, atau istishna';

c. Pembiayaan berdasarkan Akad qardh;

d. Pembiayaan penyewaan barang bergerak atau tidak bergerak kepada Nasabah berdasarkan Akad ijarah atau sewa beli dalam bentuk ijarah muntahiya bittamlik; dan

e. Pengambilalihan utang berdasarkan Akad hawalah;

3. menempatkan dana pada Bank Syariah lain dalam bentuk titipan berdasarkan Akad wadi'ah atau Investasi berdasarkan Akad mudharabah dan/atau Akad lain yang tidak bertentangan dengan Prinsip Syariah;

4. memindahkan uang, baik untuk kepentingan sendiri maupun untuk kepentingan Nasabah melalui rekening Bank Pembiayaan Rakyat Syariah yang ada di Bank Umum Syariah, Bank Umum Konvensional, dan UUS; dan

5. menyediakan produk atau melakukan kegiatan usaha Bank Syariah lainnya yang sesuai dengan Prinsip Syariah berdasarkan persetujuan Bank Indonesia.

Dalam melakukan penyaluran pembiayaan oleh Bank Syariah dan UUS harus didasarkan pada prinsip 'kelayakan penyaluran dana' sebagaimana diatur dalam pasal 23 Undang-Undang Perbankan Syariah, yang menentukan:

1. Bank Syariah dan/atau UUS harus mempunyai keyakinan atas kemauan dan kemampuan calon Nasabah Penerima Fasilitas untuk melunasi seluruh kewajiban pada waktunya, sebelum Bank Syariah dan/atau UUS menyalurkan dana kepada Nasabah Penerima Fasilitas.

2. Untuk memperoleh keyakinan sebagaimana dimaksud pada ayat (1), Bank Syariah dan/ atau UUS wajib melakukan penilaian yang saksama terhadap watak, kemampuan, modal, Agunan, dan prospek usaha dari calon Nasabah Penerima Fasilitas.

Keyakinan atas kemauan calon nasabah adalah berkaitan dengan iktikad baik dari Nasabah 
Penerima Fasilitas untuk membayar kembali penggunaan dana yang disalurkan oleh Bank Syariah dan/atau UUS, sedang keyakinan atas kemampuan berkaitan dengan keadaan dan/atau aset Nasabah Penerima Fasilitas sehingga mampu untuk membayar kembali penggunaan dana yang disalurkan oleh Bank Syariah dan/atau UUS, demikian penjelasan Pasal 23 ayat (1) UndangUndang Perbankan Syariah yariah.

Penilaian yang seksama terhadap watak, kemampuan, modal, agunan, dan prospek usaha dari calon Nasabah Penerima Fasilitas dijelaskan lebih rinci pada penjelasan Pasal 23 ayat (2) Undang-Undang Perbankan Syariah.

Penilaian watak calon Nasabah Penerima Fasilitas terutama didasarkan kepada hubungan yang telah terjalin antara Bank Syariah dan/atau UUS dan Nasabah atau calon Nasabah yang bersangkutan atau informasi yang diperoleh dari pihak lain yang dapat dipercaya sehingga Bank Syariah dan/atau UUS dapat menyimpulkan bahwa calon Nasabah Penerima Fasilitas yang bersangkutan jujur, beritikad baik, dan tidak menyulitkan Bank Syariah dan/atau UUS di kemudian hari.

Penilaian kemampuan calon Nasabah Penerima Fasilitas terutama Bank harus meneliti tentang keahlian Nasabah Penerima Fasilitas dalam bidang usahanya dan/atau kemampuan manajemen calon Nasabah sehingga Bank Syariah dan/atau UUS merasa yakin bahwa usaha yang akan dibiayai dikelola oleh orang yang tepat.

Penilaian terhadap modal yang dimiliki calon Nasabah Penerima Fasilitas, terutama Bank Syariah dan/atau UUS harus melakukan analisis terhadap posisi keuangan secara keseluruhan, baik untuk masa yang telah lalu maupun perkiraan untuk masa yang akan datang sehingga dapat diketahui kemampuan permodalan calon Nasabah Penerima Fasilitas dalam menunjang pembiayaan proyek atau usaha calon Nasabah yang bersangkutan.

Dalam melakukan penilaian terhadap agunan, Bank Syariah dan/atau UUS harus menilai barang, proyek atau hak tagih yang dibiayai dengan fasilitas Pembiayaan yang bersangkutan. Di samping itu barang lain, surat berharga atau garansi risiko yang ditambahkan sebagai agunan tambahan, apakah sudah cukup memadai sehingga apabila Nasabah Penerima Fasilitas kelak tidak dapat melunasi kewajibannya, agunan tersebut dapat digunakan untuk menanggung pembayaran kembali Pembiayaan dari Bank Syariah dan/atau UUS yang bersangkutan.

Penilaian terhadap proyek usaha calon Nasabah Penerima Fasilitas, Bank Syariah harus melakukan analisis mengenai keadaan pasar, baik di dalam maupun di luar negeri, baik untuk masa yang telah lalu maupun yang akan datang sehingga dapat diketahui prospek pemasaran dari hasil proyek atau usaha calon Nasabah yang akan dibiayai dengan fasilitas Pembiayaan.

Prinsip kelayakan penyaluran dana sebagaimana diatur dalam Pasal 23 UndangUndang Perbankan Syariah merupakan salah satu implementasi perwujudan asas kehati-hatian yang lazim dilakukan dalam dunia perbankan. Dengan demikian sudah menjadi keharusan Perbankan Syariah untuk melakukan analisis kelayakan penyaluran dana sebagai upaya untuk menjamin bahwa dana yang akan disalurkan dapat dibayar kembali oleh calon nasabah penerima failitas tanpa suatu masalah apapun.

Berkaitan dengan prinsip kehati-hatian, Undang-Undang Perbankan Syariah mengaturnya dalam Pasal 35-37. Pasal 35 Undang-Undang Perbankan Syariah menentukan:

1. Bank Syariah dan UUS dalam melakukan kegiatan usahanya wajib menerapkan prinsip kehati-hatian.

2. Bank Syariah dan UUS wajib menyampaikan kepada Bank Indonesia laporan keuangan berupa neraca tahunan dan perhitungan laba rugi tahunan serta penjelasannya yang disusun berdasarkan prinsip akuntansi syariah yang berlaku umum, serta laporan berkala lainnya, dalam waktu dan bentuk yang diatur dengan Peraturan Bank Indonesia.

3. Neraca dan perhitungan laba rugi tahunan sebagaimana dimaksud pada ayat (2) wajib terlebih dahulu diaudit oleh kantor akuntan publik.

4. Bank Indonesia dapat menetapkan pengecualian terhadap kewajiban sebagaimana dimaksud pada ayat (3) bagi Bank Pembiayaan Rakyat Syariah.

5. Bank Syariah wajib mengumumkan neraca dan laporan laba rugi kepada publik dalam waktu dan bentuk yang ditentukan oleh Bank Indonesia.

Penjelasan Pasal 35 ayat (1) menentukan, 
bahwa penerapan 'prinsip kehati-hatian' dalam rangka menjamin terlaksananya pengambilan keputusan dalam pengelolaan bank yang sesuai dengan prinsip kehati-hatian, bank memiliki dan menerapkan, antara lain, sistem pengawasan intern.

Salah satu perwujudan prinsip kehati-hatian diatur dalam Pasal Undang-Undang Perbankan Syariah, bahwa dalam menyalurkan pembiayaan dan melakukan kegiatan usaha lainnya, Bank Syariah dan UUS wajib menempuh cara-cara yang tidak merugikan Bank Syariah dan/atau UUS dan kepentingan Nasabah yang mempercayakan dananya. Cara-cara yang perlu dilakukan untuk mencegah timbulnya kerugian bagi Bank Syariah dan UUS serta nasabah yang mempercayakan dananya diatur dalam Pasal 37 UU Perbankan yaitu:

1. Bank Indonesia menetapkan ketentuan mengenai batas maksimum penyaluran dana berdasarkan Prinsip Syariah, pemberian jaminan, penempatan investasi surat berharga yang berbasis syariah, atau hal lain yang serupa, yang dapat dilakukan oleh Bank Syariah dan UUS kepada Nasabah Penerima Fasilitas atau sekelompok Nasabah Penerima Fasilitas yang terkait, termasuk kepada perusahaan dalam kelompok yang sama dengan Bank Syariah dan UUS yang bersangkutan.

2. Batas maksimum sebagaimana dimaksud pada ayat (1) tidak boleh melebihi 30\% (tiga puluh persen) dari modal Bank Syariah sesuai dengan ketentuan yang ditetapkan oleh Bank Indonesia.

3. Bank Indonesia menetapkan ketentuan mengenai batas maksimum penyaluran dana berdasarkan Prinsip Syariah, pemberian jaminan, penempatan investasi surat berharga, atau hal lain yang serupa yang dapat dilakukan oleh Bank Syariah kepada:

a. pemegang saham yang memiliki $10 \%$ (sepuluh persen) atau lebih dari modal disetor Bank Syariah;

b. anggota dewan komisaris;

c. anggota direksi;

d. keluarga dari pihak sebagaimana dimaksud dalam huruf a, huruf $b$, dan huruf c;

e. pejabat bank lainnya; dan

f. perusahaan yang di dalamnya terdapat kepentingan dari pihak sebagaimanadimaksud dalam huruf a sampai dengan huruf e.

4. Batas maksimum sebagaimana dimaksud pada ayat (3) tidak boleh melebihi $20 \%$ (dua puluh persen) dari modal Bank Syariah sesuai dengan ketentuan yang ditetapkan oleh Bank Indonesia.

5. Pelaksanaan ketentuan sebagaimana dimaksud pada ayat (1) dan ayat (3) wajib dilaporkan sesuai dengan ketentuan yang ditetapkan oleh Bank Indonesia.

Dasar pemikiran penetapan ketentuan mengenai batas maksimum penyaluran dana berdasarkan Prinsip Syariah sebagaimana diatur dalam Pasal 35 ayat (1) Undang-Undang Perbankan Syariah, dapat dilihat pada penjelasan Pasal 37 ayat (1) Undang-Undang Perbankan Syariah sebagai berikut:

"Penyaluran dana berdasarkan Prinsip Syariah oleh Bank Syariah dan UUS mengandung risiko kegagalan atau kemacetan dalam pelunasannya sehingga dapat berpengaruh terhadap kesehatan Bank Syariah dan UUS. Mengingat bahwa penyaluran dana dimaksud bersumber dari dana masyarakat yang disimpan pada Bank Syariah dan UUS, risiko yang dihadapi Bank Syariah dan UUS dapat berpengaruh pula kepada keamanan dana masyarakat tersebut. Oleh karena itu, untuk memelihara kesehatan dan meningkatkan daya tahannya, bank diwajibkan menyebar risiko dengan mengatur penyaluran kredit atau pemberian pembiayaan berdasarkan Prinsip Syariah, pemberian jaminan ataupun fasilitas lain sedemikian rupa sehingga tidak terpusat pada Nasabah debitur atau kelompok Nasabah debitur tertentu"

Batas maksimum yang dimaksud diperuntukkan bagi masing-masing Nasabah Penerima Fasilitas atau sekelompok Nasabah Penerima Fasilitas termasuk perusahaan-perusahaan dalam kelompok yang sama, dengan maksud agar penyaluran dana tidak hanya diberikan kepada perorangan, perusahaan atau kelompok perusahaan tertentu saja, demikian penjelasan Pasal 37 ayat (2) Undang-Undang Perbankan Syariah.

Disadari sepenuhnya bahwa menghimpun dan menyalurkan dana selalu akan menimbulkan 
resiko kerugian. Untuk itu, Pasal 38 UndangUndang Perbankan Syariah mewajibkan beberapa kegiatan, yaitu:

1. Bank Syariah dan UUS wajib menerapkan manajemen risiko, prinsip mengenal nasabah, dan perlindungan nasabah.

2. Ketentuan sebagaimana dimaksud pada ayat (1) diatur dengan Peraturan Bank Indonesia.

Menurut penjelasan Pasal 38 ayat (1) Undang-Undang Perbankan Syariah, bahwa yang dimaksud dengan manajemen risiko adalah serangkaian prosedur dan metodologi yang digunakan oleh perbankan untuk mengidentifikasi, mengukur, memantau, dan mengendalikan risiko yang timbul dari kegiatan usaha bank. Sedang prinsip mengenal nasabah (know how customer principle) sebagaimana diungkapkan oleh Bismar Nasution merupakan prinsip yang harus diterapkan oleh perbankan untuk mengetahui kegiatan penerimaan dan identifikasi nasabah serta pemantauan kegiatan transaksi Nasabah, termasuk pelaporan transaksi yang mencurigakan dan sudah menjadi kewajiban bank untuk menerapkannya ${ }^{5}$. Perlindungan nasabah dilakukan antara lain dengan cara adanya mekanisme pengaduan nasabah, meningkatkan transparansi produk, dan edukasi terhadap nasabah.

Berkaitan dengan resiko yang akan diterima oleh nasabah, sesuai dengan ketentuan Pasal 39 Undang-Undang Perbankan Syariah, Bank Syariah dan UUS wajib menjelaskan kepada nasabah mengenai kemungkinan timbulnya risiko kerugian sehubungan dengan transaksi nasabah yang dilakukan melalui Bank Syariah dan/atau UUS. Penjelasan yang diberikan kepada nasabah mengenai kemungkinan timbulnya risiko kerugian dimaksudkan untuk menjamin transparansi produk dan jasa Bank. Apabila informasi tersebut telah disediakan, Bank dianggap telah melaksanakan ketentuan ini (penjelasan Pasal 39 UndangUndang Perbankan Syariah).

Salah satu aspek pengelolaan resiko adalah pengambil-alihan agunan sebagai upaya pengaman agar dana yang telah disalurkan dapat dibayarkan kembali. Hal ini diatur dalam Pasal 40 UndangUndang Perbankan Syariah, sebagai berikut:

1. Dalam hal Nasabah Penerima Fasilitas tidak memenuhi kewajibannya, Bank Syariah dan UUS dapat membeli sebagian atau seluruh Agunan, baik melalui maupun di luar pelelangan, berdasarkan penyerahan secara sukarela oleh pemilik Agunan atau berdasarkan pemberian kuasa untuk menjual dari pemilik Agunan, dengan ketentuan Agunan yang dibeli tersebut wajib dicairkan selambat-lambatnya dalam jangka waktu 1 (satu) tahun.

2. Bank Syariah dan UUS harus memperhitungkan harga pembelian Agunan sebagaimana dimaksud pada ayat (1) dengan kewajiban Nasabah kepada Bank Syariah dan UUS yang bersangkutan.

3. Dalam hal harga pembelian Agunan sebagaimana dimaksud pada ayat (1) melebihi jumlah kewajiban Nasabah lepada Bank Syariah dan UUS, selisih kelebihan jumlah tersebut harus dikembalikan kepada Nasabah setelah dikurangi dengan biaya lelang dan biaya lain yang langsung terkait dengan proses pembelian Agunan.

4. Ketentuan lebih lanjut mengenai pembelian Agunan sebagaimana dimaksud pada ayat (1), ayat (2), dan ayat (3) diatur dengan Peraturan Bank Indonesia.

Menurut penjelasan Pasal 40 ayat (1) Undang-Undang Perbankan Syariah, bahwa pembelian agunan oleh Bank melalui pelelangan dimaksudkan untuk membantu Bank agar dapat mempercepat penyelesaian kewajiban Nasabah Penerima Fasilitasnya. Dalam hal bank sebagai pembeli Agunan Nasabah Penerima Fasilitasnya, status Bank adalah sama dengan pembeli bukan Bank lainnya. Bank dimungkinkan membeli agunan di luar pelelangan dimaksudkan agar dapat mempercepat penyelesaian kewajiban Nasabah Penerima Fasilitasnya. Batas waktu 1 (satu) tahun dengan memperhitungkan pemulihan kondisi likuiditas Bank dan batas waktu ini merupakan jangka waktu yang wajar untuk menjual aset Bank. Agunan yang dapat dibeli oleh Bank adalah agunan yang pembiayaannya telah dikategorikan macet selama jangka waktu tertentu.

Sehubungan dengan ketentuan lebih lanjut tentang pembelian agunan, penjelasan Pasal 40 ayat (4) Undang-Undang Perbankan Syariah menentukan bahwa:

5. Bismar Nasution, Rezim Anti Money Laundering di Indonesia, Book Terrance dan Library, Bandung, 2005, hlm. 43. 
Pokok-pokok ketentuan yang diatur lebih lanjut dengan Peraturan Bank Indonesia memuat antara lain:

1. Agunan yang dapat dibeli oleh Bank Syariah dan UUS adalah Agunan yang pembiayaannya telah dikategorikan macet selama jangka waktu tertentu;

2. Jangka waktu pencairan Agunan yang telah dibeli".

Mencermati aturan hukum sebagaimana telah diuraikan sebelumnya, dapatlah dikatakan bahwa aturan hukum Undang-Undang Perbankan Syariah tentang berbagai kegiatan usaha perbankan syariah terutama aspek 'pembiayaan atau penyaluran dana' telah mencerminkan esensi perikatan syariah, bahkan rumusan pasal akan mampu mengakomodasi perkembangan perikatan syariah, karena rumusan pasal dalam bentuk enumeratif.

Beberapa contoh aturan hukum yang dirumuskan dalam bentuk 'enumeratif', misalnya yang terdapat dalam Pasal 19 ayat (1) UU Perbankan Syariah, seperti:

a. menyalurkan Pembiayaan bagi hasil berdasarkan Akad mudharabah, Akad musyarakah, atau Akad lain yang tidak bertentangan dengan Prinsip Syariah;

b. menyalurkan Pembiayaan berdasarkan Akad murabahah, Akad salam, Akad istishna, atau Akad lain yang tidak bertentangan dengan Prinsip Syariah;

c. menyalurkan Pembiayaan berdasarkan Akad qardh atau Akad lain yang tidak bertentangan dengan Prinsip Syariah;

d. menyalurkan Pembiayaan penyewaan barang bergerak atau tidak bergerak kepada Nasabah berdasarkan Akad ijarah dan/atau sewa beli dalam bentuk ijarah muntahiya bittamlik atau Akad lain yang tidak bertentangan dengan Prinsip Syariah;

e. melakukan pengambilalihan utang berdasarkan Akad hawalah atau Akad lain yang tidak bertentangan dengan Prinsip Syariah;

Dari rumusan-rumusan aturan hukum di atas, jelas bahwa Undang-Undang Perbankan Syariah tidak membatasi 'akad' (perikatan syariah) untuk pembiayaan sebatas mudharabah, musyarakah, murabahah, salam, istishna, qardh, ijarah, ijarah muntahiya bittamlik, serta hawalah, tetapi dapat mengakomodasi akad-akad lain selama tidak bertentangan dengan prinsip syariah. Rumusan yang demikian ini, sesuai dengan kaidah Fiqih yaitu 'pada dasarnya segala bentuk muamalat boleh dilakukan kecuali ada dalil yang mengharamkannya'.

Dengan demikian, dapat disimpulkan bahwa Undang-Undang Perbankan Syariah sudah mengimplementasikasikan esensi perikatan syariah. Selanjutnya yang perlu dibahas adalah apakah Undang-Undang Perbankan Syariah sudah mengimplementasikan esensi jaminan syariah (al-rahn) dalam aturan hukumnya.

Jika dicermati, terdapat beberapa pasal dalam Undang-Undang Perbankan Syariah yang mengatur tentang jaminan (dalam UndangUndang Perbankan Syariah dinamakan agunan). Menurut Pasal 1 angka 26 Undang-Undang Perbankan Syariah, yang dimaksud Agunan adalah jaminan tambahan, baik berupa benda bergerak maupun benda tidak bergerak yang diserahkan oleh pemilik Agunan kepada Bank Syariah dan/ atau UUS, guna menjamin pelunasan kewajiban Nasabah Penerima Fasilitas.

Dari rumusan di atas, Undang-Undang Perbankan Syariah pada prinsipnya tidak menempatkan agunan sebagai jaminan utama. Ini berarti, Agunan tidak mutlak harus ada pada saat dibuatnya suatu perikatan syariah yang berbentuk pembiayaan. Agunan merupakan salah satu aspek yang harus dinilai pada saat Bank Syariah atau UUS akan menyalurkan dananya. Bank Syariah atau UUS wajib mempunyai keyakinan atas 'kelayakan penyaluran dana' sehingga dana yang telah disalurkan akan dapat dibayar oleh nasabah penerima fasilitas. Kewajiban ini diatur dalam Pasal 23 Undang-Undang Perbankan Syariah. Pasal 23 ayat (2) Undang-Undang Perbankan Syariah menegaskan, bahwa untuk mendapatkan keyakinan kelayakan penyaluran dana, Bank Syariah atau UUS wajib melakukan penilaian terhadap agunan yang disertakan.

Penilaian yang seksama terhadap agunan ini harus dilakukan sampai Bank Syariah atau UUS berkyakinan bahwa nilai agunan sudah cukup memadai, sehingga jika nasabah penerima fasilitas tidak dapat melunasi kewajibannya, agunan tersebut dapat digunakan untuk menanggung pembayaran kembali.

Signifikansi keberadaan agunan dalam akad (perikatan syariah) dapat dilihat pada salah 
satu aspek pengelolaan resiko, yaitu pembelian agunan untuk mengamankan pengembalian dana yang telah disalurkan sebagaimana diatur dalam Pasal 40 Undang-Undang Perbankan Syariah. Jika nasabah penerima fasilitas tidak memenuhi kewajibannya, Bank Syariah dapat membeli sebagian atau seluruh Agunan, baik melalui lelang atau tidak, berdasarkan 'penyerahan sukarela' atau pemberian 'kuasa untuk untuk menjual' dari pemilik agunan, dengan syarat agunan yang dibeli tersebut harus sudah dicairkan paling lambat dalam jangka waktu 1 (satu) tahun.

Selain itu, Bank Syariah atau UUS harus memperhitungkan harga pembelian agunan dengan kewajiban yang harus dibayar oleh nasabah. Jika ternyata harga pembelian melebihi jumlah kewajiban nasabah, maka selisih kelebihan harus dikembalikan kepada nasabah setelah dikurangi dengan biaya lelang dan biaya lain yang langsung terkait dengan proses pembelian agunan.

Dasar pemikiran konsep pembelian agunan tersebut di atas adalah membantu Bank agar dapat mempercepat penyelesaian kewajiban Nasabah Penerima Fasilitasnya. Batas waktu 1 (satu) tahun dengan memperhitungkan pemulihan kondisi likuiditas Bank dan batas waktu ini merupakan jangka waktu yang wajar untuk menjual aset Bank. Agunan yang dapat dibeli oleh Bank adalah Agunan yang pembiayaannya telah dikategorikan macet selama jangka waktu tertentu. Dalam Pasal 40 ayat (4) UU Perbankan ditentukan, bahwa ketentuan lebih lanjut mengenai pembelian agunan diatur dengan Peraturan Bank Indonesia.

Rejim UU Perbankan Syariah ternyata hanya mengatur keberadaan dan peran agunan secara sumir (terbatas). Padahal, selain Syariah telah mengatur agunan, yang dinamakan Jaminan Syariah (al-rahn) secara komprehenif, juga jiwa atau semangat UU Perbankan Syariah yang berkehendak untuk melaksanakan syariah secara kaffah (holistik) dan istiqomah (konsisten).

Sebelum membahas lebih lanjut persoalan ini, ada baiknya mencermati pokok-pokok pikiran yang mendasari munculnya UU Perbankan Syariah sebagaimana terdapat dalam Penjelasan Umum UU Perbankan Syariah sebagai berikut:

1. Salah satu bentuk penggalian potensi dan wujud kontribusi masyarakat dalam perekonomian nasional tersebut adalah pengembangan sistem ekonomi berdasarkan nilai
Islam (Syariah) dengan mengangkat prinsipprinsipnya ke dalam Sistem Hukum Nasional. Prinsip Syariah berlandaskan pada nilai-nilai keadilan, kemanfaatan, keseimbangan, dan keuniversalan (rahmatan lil alamin). Nilainilai tersebut diterapkan dalam pengaturan perbankan yang didasarkan pada Prinsip Syariah yang disebut Perbankan Syariah;

2. Sebagaiundang-undang yang khusus mengatur perbankan syariah, dalam Undang-Undang ini diatur mengenai masalah kepatuhan syariah (syariah compliance) yang kewenangannya berada pada Majelis Ulama Indonesia (MUI) yang direpresentasikan melalui Dewan Pengawas Syariah (DPS) yang harus dibentuk pada masing-masing Bank Syariah dan UUS. Untuk menindaklanjuti implementasi fatwa yang dikeluarkan MUI ke dalam Peraturan Bank Indonesia, di dalam internal Bank Indonesia dibentuk komite perbankan syariah, yang keanggotaannya terdiri atas perwakilan dari Bank Indonesia, Departemen Agama, dan unsur masyarakat yang komposisinya berimbang.

Berdasarkan pada Penjelasan Umum Undang-Undang Perbankan Syariah, dapat dikatakan bahwa dasar pemikiran dibentuknya Undang-Undang Perbankan Syariah adalah mengimplementasikan prinsip-prinsip syariah ke dalam sistem hukum nasional, khususnya perundang-undangan perbankan syariah. Selain itu, pada tataran praktis, implementasi ini dilaksanakan dalam kerangka kepatuhan syariah (syariah compliance). Penentuan prinsip-prinsip syariah dalam hal ini muamalah (khususnya perikatan syariah dan jaminan syariah) merupakan kewenangan Majelis Ulama Indonsia (MUI). Implementasi penetapan prinsip-prinsip syariah pada masing-masing Bank Syariah dan UUS dilakukan oleh Dewan Pengawas Syariah (DPS) yang harus dibentuk pada masing-masing institusi perbankan syariah. Selain itu, untuk menindaklanjuti fatwa tersebut ke dalam Peraturan Bank Indonesia dilakukan oleh Komite Perbankan Syariah yang dibentuk secara internal di Bank Indonesia.

Sebagai tambahan dalam Peraturan Bank Indonesia Nomor 7/46/PBI/2005 tentang Akad Penghimpunan dan Penyaluran Dana Bagi Bank yang Melaksanakan Kegiatan Usaha Berdasarkan Prinsip Syariah, lebih menitik beratkan pada 
jenis-jenis akad penghimpunan dan penyaluran dana pada perbankan syariah seperti wadi'ah, mudharabah, musyarakah, murabaha, Salam, Istishna, Ijarah dan Qardh yang disertai dengan persyaratan yang melingkupinya. Di dalam peraturan PBI tersebut tidak secara jelas di atur tentang jaminan syariah.

Dari dasar pemikiran tersebut di atas, dapat dikatakan bahwa seharusnya Undang-Undang Perbankan Syariah mengimplementasikan konsep Jaminan Syariah (al-rahn) dalam aturan hukumnya, bukan hanya mengatur Perikatan Syariah (Akad) terutama dalam hal pembiayaan. Dalam sistem Hukum Syariah paling tidak terdiri atas 2 (dua) unsur atau subsistem, yaitu Perikatan Syariah (Akad) dan Jaminan Syariah (Al-rahn). Antara subsistem Perikatan Syariah dengan susbsistem Jaminan Syariah mempunyai pola hubungan yang erat, karena keberadaan subsistem Jaminan Syariah merupakan bagian integral dari Perikatan Syariah.

\section{Penutup}

Dari analisis permasalahan yang dikemukakan di atas dapat disimpulkan bahwa implementasi jaminan syariah dalam tataran tata aturan perundang-undangan dalam hal ini UndangUndang Perbankan belum di atur secara tegas.

\section{DAFTAR PUSTAKA}

\section{Buku}

Abdullah bin Muhammad Al Thoyaar, $1425 \mathrm{H}, \boldsymbol{A l}$ Fiqh Al Muyassarah, Qismul Mu'amalah Cet.I, Madar Al Wathoni LinNasyr, Riyadh.

Ala' Eddin Kharofa, 1997, Transactions in Islamic Law,: A.S. NOORDEEN, Kuala Lumpur.

Bismar Nasution, 2005, Rezim Anti Money Laundering di Indonesia, Book Terrance dan Library, Bandung.

Gemala Dewi, 2006, Hukum Perikatan Islam di Indonesia, Kencana, Jakarta.

Sayyid As-Sabiq, 1995, Al-Fiqh As-Sunnah, Daar Al-Fikr, Beirut.

\section{Peraturan Perundang-undangan}

Undang-Undang Nomor 10 Tahun 1998 Tentang Perubahan Atas UU Nomor 7 Tahun 1992 Tentang Perbankan.

Undang-Undang Nomor 21 Tahun 2008 Tentang Perbankan Syariah.

Peraturan Bank Indonesia Nomor 7/46/PBI/2005 tentang Akad Penghimpunan dan Penyaluran Dana Bagi Bank yang Melaksanakan Kegiatan Usaha Berdasarkan Prinsip Syariah. 